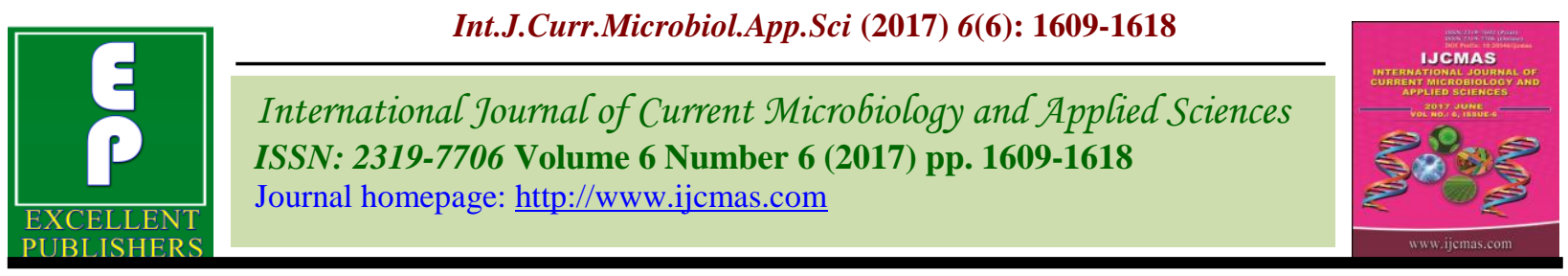

Original Research Article

https://doi.org/10.20546/ijcmas.2017.606.189

\title{
Characterization of Mungbean (Vigna radiata L. Wilczek) Varieties using Morphological and Molecular Descriptors
}

\author{
Rupinder Kaur ${ }^{1 *}$, A.K. Toor ${ }^{1}$, Geeta Bassi ${ }^{1}$ and T.S. Bains ${ }^{2}$ \\ ${ }^{1}$ Seed Technology Centre; ${ }^{2}$ Pulses Section Department of Plant Breeding and Genetics, \\ Punjab Agricultural University, Ludhiana, Punjab141004 \\ *Corresponding author
}

\begin{tabular}{|c|c|}
\hline & A B S T R A C T \\
\hline & \multirow{6}{*}{$\begin{array}{l}\text { Five mungbean varieties released by Punjab Agricultural University (PAU911, SML668, } \\
\text { ML818, ML613 and SML832) were characterized using morphological and molecular } \\
\text { markers. Phenotypically these varieties showed variation for growth habit, leaf and flower } \\
\text { characters, pod colour, position and length, plant height, seed coat lusture and seed size } \\
\text { during different growth stages of the crop. Plant morphology characters being polygenic in } \\
\text { nature are liable to be influenced by the environment. Hence there is a need to use alternate } \\
\text { descriptors which are rapid, accurate and less affected by environment. Therefore, in the } \\
\text { present study, simple sequence repeats (SSR) markers were also used for determining } \\
\text { genetic diversity analysis and supplementing morphological data. Five mungbean varieties } \\
\text { were analysed using } 44 \text { SSR molecular markers, covering the whole genome of } \\
\text { greengram. Out of } 44 \text { primers screened primers RG6, RG7, RG8, RG11, RG14, RG15 and } \\
\text { MBM00101exhibited distinct banding pattern. Markers RG6 and RG7 differentiate the } \\
\text { variety ML818 and SML832. Marker RG11 distinguished ML818 and ML613. Similarly, } \\
\text { primers RG8, RG11, RG14 and RG15 showed distinctive banding pattern among the } \\
\text { SML832 and ML613. Primer MBM001101 indicated polymorphism among PAU } 911 \text { and } \\
\text { SML668. The UPGMA dendrogram based on similarity co-efficient showed maximum } \\
\text { genetic difference between ML613 and ML818 and maximum similarity between ML818 } \\
\text { and SML668. }\end{array}$} \\
\hline Keywords & \\
\hline $\begin{array}{l}\text { Genetic diversity, } \\
\text { greengram, } \\
\text { morphological } \\
\text { markers, } \\
\text { SSR markers. }\end{array}$ & \\
\hline Ar & \\
\hline & \\
\hline & \\
\hline
\end{tabular}

\section{Introduction}

Mungbean (Vigna radiate L. Wilczek) or green gram is an important legume crop. It is a great source of proteins, vitamins, and minerals, particularly in South Asia. It is a self-pollinated crop having $2 \mathrm{n}=2 \mathrm{x}=22$ chromosomes with a genome size of 579 $\mathrm{Mb} / 1 \mathrm{C}$. Its capacity to restore soil fertility through nitrogen fixation makes it a valuable crop in various cropping systems, particularly wheat-rice. The Productivity of mungbean is very low i.e. only around $500 \mathrm{~kg}$ per ha. The low productivity can be attributed to narrow genetic base and lack of suitable genotypes for different cropping situations (Dikshit et al., (2009). Being major producer of mungbean, India has developed a large number of commercial cultivars. These varieties are characterised by high degree of homogeneity. The traditional method of variety characterisation is the field sown; grow out test which involves examination of plants from vegetative stage to maturity. This is time consuming since it covers the entire duration of the crop which may extend up to 
100 days. Moreover, plant morphology characters being polygenic in nature are liable to be influenced by the environment. Hence there is a need to use alternate descriptors which are rapid, accurate and less affected by environment. Several molecular marker types are available and each has their advantages and disadvantages (Manivannam et al., 2016). The molecular marker based seed purity assay could be a better alternative and is receiving more attention as these are not influenced by genotype and environment interactions, making DNA barcoding as the most straight forward method for cultivar identification (Naresh et al., 2009). A few PCR-based DNA markers, including random-amplified polymorphic DNA (RAPD), sequence-tagged microsatellite site (STMS), single nucleotide polymorphism (SNP), and simple sequence repeat (SSR) has been developed in mungbean (Van et al., 2013). Among them SSR markers or microsatellites (Litt et al., 1989), have been widely used for investigating the genetic relatedness and diversity in plant population and cultivars (Bornet et al., 2006). SSR markers are important owing to their co-dominant inheritance, relative abundance, high reproducibility, polymorphism, and simplicity of genotyping (Tautz et al., 1984; Varshney et al., 2005). Present studies were therefore undertaken to evaluate morphological and molecular characterisation for their genetic diversity.

\section{Materials and Methods}

The experimental material consisted of breeder seed of five mungbean (Vigna radiata L. Wilczek) varieties released by Punjab Agricultural University, Lidhiana viz.PAU911, SML668, ML818, ML613 and SML832. These were planted during March 2014 and 2015 at research farm of Pulses Section of Department of Plant Breeding and Genetics, PAU Ludhiana. For morphological characterisation, all varieties were planted in four rows (5 meters Long) at $45 \mathrm{~cm}$ distance in three replications. The plant to plant distance was kept at $15 \mathrm{~cm}$. The observations on morphological characters were recorded during different growth stages. The anthocyanin pigmentation at cotyledonary stage was observed at unfolded stage (5 days after sowing). Similarly, characters like growth habit, plant habit, stem colour, leaf colour, vein colour, leaf size, petiole colour and stem pubescence observed at 50\% flowering stage. For the assessment of colour characteristics, the latest Royal Horticultural Society (RHS) colour chart was used. While characters like plant height, premature pod colour were observed when pods were fully developed. Pod colour at maturity, pod curvature, pod position and mature pod length were observed at maturity stage of the crop. Seed characters i.e. seed colour, seed coat lusture, seed shape, seed size were observed after harvest. All morphological observations were conducted as per DUS testing guidelines by Protection of Plant Varieties \& Farmers' Rights Authority (2007). For molecular analysis whole seedling of each genotype, after removing the seed coat from 7 to 8 days old seedlings, were used for DNA extraction. Genomic DNA was isolated using the CTAB method (Saghai-Maroof et al., 1984) and DNA concentration was estimated using DNA nanodrop. These estimates were confirmed by staining DNA with ethidium bromide after electrophoresis on 0.8 per cent agarose gel at $100 \mathrm{~V}$ for $1 \mathrm{~h}$ in TAE buffer $(0.4 \mathrm{M}$ Trisacetate, $0.001 \mathrm{M}$ EDTA, pH 8.0). Ethidium bromide-stained gel was visualized and documented with the help of Gel Documentation System. PCR conditions were standardized using varying concentrations of primers and template DNA. After standardization, the reaction mixture was prepared in $20 \mu \mathrm{L}$ volume containing $40 \mathrm{ng}$ of template DNA, 1X final concentration of Taq buffer $\mathrm{B}, 25 \mathrm{mM} \mathrm{MgCl}_{2}, 5.0 \mu \mathrm{M}$ of each 
forward and reverse primer, $2.5 \mathrm{mM}$ of deoxynucleotide triphosphates (dNTPs) and $0.03 \mathrm{U}$ of Taq, DNA polymerase $(5 \mathrm{U} \mu \mathrm{L}-1)$ and run on a thermo cycler (mastercycler PCR System; Eppendorf). The PCR conditions used for amplification of SSRs consisted of initial denaturation at $94^{\circ} \mathrm{C}$ for $45 \mathrm{~s}$, followed by 38 cycles, each consisting of denaturation at $94^{\circ} \mathrm{C}$ for $30 \mathrm{~s}$, annealing at $50-60^{\circ} \mathrm{C}$ for 1 min, and elongation at $72^{\circ} \mathrm{C}$ for $45 \mathrm{~s}$, with a final extension at $72^{\circ} \mathrm{C}$ for $10 \mathrm{~min}$. The PCR amplified products were resolved on $3.0 \%$ agarose gel electrophoresis in $0.5 \%$ TAE buffer at a constant power supply with known concentration of DNA ladder $\left(50 \mathrm{ng} \mu \mathrm{L}^{-1}\right.$; Thermo Scientific) as a molecular weight marker. Ethidium bromide-stained gels were visualized and photographed by using the Gel Documentation System. SSR alleles were scored for the lower molecular weight and higher molecular weight of the SSR marker bands. The amplified products for SSR analysis was scored visually based on molecular size of the band for each marker. Each fragment was treated as a unit and only clear and unambiguous bands were scored. The similarity co- efficients were used to construct a dendrogram for determining relationship using unweighted pair group method with arithmetic average (UPGMA).

\section{Results and Discussion}

\section{Morphological characterization}

Anthocyanin colouration recorded at seedling stage was present in all the varieties and hence indicated no variation. Other characters viz. plant habit, stem colour, stem pubescence, petiole colour, premature pod colour, pod pubescence, pod curvature, seed colour and seed shape, exhibited similar characteristics among all the varieties. Phenotypic data is presented in table 1, for growth habit, leaf colour, leaf size, flower colour and vein colour was recorded at $50 \%$ flowering stage. It indicated that $c v$. SML613 had semi erect growth habit while other varieties had erect growth habit. SML 668 and SML832 exhibited dark green leaf colour and PAU911, ML818 and ML613 showed green leaf colour. Likewise, for leaf size three types of observations were registered i.e. ML818 and ML613 had medium size leaf, while SM668 and SML832 were observed with broad leaf and PAU911 had large leaf size. Flower colour was yellow in variety PAU911, while remaining all were distinct with respect to light yellow colour. The vein colour was greenish purple in PAU911 and light purple in all other varieties. Assessment of characteristics like plant height and pod position was recorded at fully developed green pod stage. Varieties like SML668 and SML832 remained dwarf $(<50 \mathrm{~cm})$ while varieties PAU911, ML818 and ML613 were medium tall $(50-70 \mathrm{~cm})$. The pod position was observed above the canopy in PAU911, SML 668 and SML832 and below the canopy in ML613 and ML818. Characteristics like pod colour at maturity and pod length were recorded during maturity. Varieties PAU911 and ML668 exhibited dark brown podcolour while varieties SML 668 and SM1832 had blackish brown pod colour and ML613 produced brown cloured pods. Likewise, pod length was observed to be medium long in ML613 and SML832 and long in PAU911, SML668 and ML818. The characteristics of seed coat luster and seed size was analyzed at mature seed stage. The seed coat luster for variety SML668 was medium shining while for all others it was shining. On the other hand seed size grouped the varieties into three categories, i.e. medium for PAU911, SML818, ML613 and bold size in variety SML668. Third type was of medium bold in the variety SML832. Though these morphological characters could distinguish some varieties in both the seasons but there were few plants in the group of 50 plants under observation which indicated some deviations at certain points of growth stages. 
Table.1 Morphological characters in different mungbean varieties

\begin{tabular}{|c|c|c|c|c|c|c|}
\hline \multirow{2}{*}{ Characters } & \multirow{2}{*}{\begin{tabular}{|l} 
Stage of \\
observation
\end{tabular}} & \multicolumn{5}{|l|}{ Varieties } \\
\hline & & \begin{tabular}{|l|} 
PAU911 \\
\end{tabular} & \begin{tabular}{|l|} 
SML668 \\
\end{tabular} & ML818 & ML613 & SML832 \\
\hline $\begin{array}{l}\text { Hypocotyl: } \\
\text { Anthocyanin } \\
\text { colouration }\end{array}$ & $\begin{array}{l}\text { Cotyledons } \\
\text { unfolded }\end{array}$ & Present & Present & Present & Present & Present \\
\hline Plant type & $50 \%$ flowering & Erect & Erect & Erect & Semi-erect & Erect \\
\hline Plant growth habit & $50 \%$ flowering & Determinate & Determinate & Determinate & Determinate & Determinate \\
\hline Stem colour & $50 \%$ flowering & Green & Green & Green & Green & Green \\
\hline Stem pubescence & $50 \%$ flowering & Present & Present & Present & Present & Present \\
\hline Leaf colour & $50 \%$ flowering & Green & Dark Green & Green & Green & Dark Green \\
\hline Vein colour & $50 \%$ flowering & Greenish purple & Light purple & Light purple & Light purple & Light purple \\
\hline Petiole colour & $50 \%$ flowering & \begin{tabular}{|l|} 
Greenish purple \\
\end{tabular} & Greenish purple & Greenish purple & \begin{tabular}{|l|} 
Greenish purple \\
\end{tabular} & Greenish purple \\
\hline Leaf size & $50 \%$ flowering & Large & Broad & Medium & Medium & Broad \\
\hline Flower colour & $50 \%$ flowering & Yellow & Light yellow & Light yellow & Light yellow & Light yellow \\
\hline $\begin{array}{l}\text { Premature pod } \\
\text { colour }\end{array}$ & $\begin{array}{l}\text { Fully developed } \\
\text { green pod }\end{array}$ & Green & Green & Green & Green & Green \\
\hline Pod pubescence & $\begin{array}{l}\text { Fully developed } \\
\text { green pod }\end{array}$ & Present & Present & Present & Present & Present \\
\hline Pod position & $\begin{array}{l}\text { Fully developed } \\
\text { green pod }\end{array}$ & Above canopy & Above canopy & Below canopy & Below canopy & Above canopy \\
\hline Plant height & $50 \%$ flowering & Medium tall & Dwarf & Medium tall & Medium tall & Dwarf \\
\hline Days to Maturity & Harvest maturity & 75 & 60 & 80 & 85 & 61 \\
\hline $\begin{array}{l}\text { Pod colour at } \\
\text { maturity }\end{array}$ & Harvest maturity & Dark brown & Blackish brown & Dark brown & Black & Blackish brown \\
\hline Pod curvature & Harvest maturity & $\begin{array}{l}\text { Slightly curved at } \\
\text { beak }\end{array}$ & $\begin{array}{l}\text { Slightly curved at } \\
\text { beak }\end{array}$ & $\begin{array}{l}\text { Slightly curved at } \\
\text { beak }\end{array}$ & $\begin{array}{l}\text { Slightly curved at } \\
\text { beak }\end{array}$ & $\begin{array}{l}\text { Slightly curved at } \\
\text { beak }\end{array}$ \\
\hline $\begin{array}{l}\text { Mature pod length } \\
(<8 \mathrm{~cm})\end{array}$ & Harvest maturity & Long & Long & Long & Medium long & Medium long \\
\hline Seed colour & Mature seeds & Green & Green & Green & Green & Green \\
\hline Seed coat lusture & Mature seeds & Shining & Medium shining & Shining & Shining & Shining \\
\hline Seed shape & Mature seeds & Oblong/Oval & Oblong & \begin{tabular}{|l} 
Oblong \\
\end{tabular} & \begin{tabular}{|l} 
Oblong \\
\end{tabular} & Oblong \\
\hline $\begin{array}{l}\text { Seed size }(3.5 \mathrm{~g} / 100 \\
\text { seed) }\end{array}$ & Mature seeds & Medium & Bold & Medium & Medium & Medium Bold \\
\hline No. of grains per pod & Maturity & $9-11$ & 10-11 & $10-1$ & $11-12$ & 10 \\
\hline Yield qlts/ha & Maturity & 4.9 & 4.5 & 4.9 & 4.3 & 4.6 \\
\hline
\end{tabular}


Table.2 Markers used for genetic diversity in mungbean

\begin{tabular}{|c|c|c|c|}
\hline Sr.No. & Marker & Sr.No. & Marker \\
\hline 1 & RG1 & 23 & MBM00037 \\
\hline 2 & $\mathrm{RG} 2$ & 24 & VRO274 \\
\hline 3 & RG3 & 25 & VRO244 \\
\hline 4 & RG4 & 26 & MBM0002 \\
\hline 5 & RG5 & 27 & VR0487 \\
\hline 6 & RG6 & 28 & VRO413 \\
\hline 7 & RG7 & 29 & VRO393 \\
\hline 8 & RG8 & 30 & VRO390 \\
\hline 9 & RG9 & 31 & MBM00012 \\
\hline 10 & RG10 & 32 & MBM00023 \\
\hline 11 & RG11 & 33 & MBM00036 \\
\hline 12 & RG12 & 34 & MBM00042 \\
\hline 13 & RG13 & 35 & MBM00011 \\
\hline 14 & RG14 & 36 & MBM00101 \\
\hline 15 & RG15 & 37 & MBM00082 \\
\hline 16 & VR0248 & 38 & MBM00097 \\
\hline 17 & VR0135 & 39 & MBM00060 \\
\hline 18 & VR0133 & 40 & MBM00049 \\
\hline 19 & VRO73 & 41 & MBM00171 \\
\hline 20 & VRO95 & 42 & MBM00173 \\
\hline 21 & VRO375 & 43 & MBM00106 \\
\hline 22 & VR0361 & 44 & MBM00155 \\
\hline
\end{tabular}

Table.3 Maker analysis indicating polymorphism in different varieties of mungbean

\begin{tabular}{|l|l|l|}
\hline Sr. No. & Polymorphic marker & Variety \\
\hline 1. & RG6 & ML818,SML832 \\
\hline 2. & RG7 & ML818,SML832 \\
\hline 3. & RG8 & SML832,ML613 \\
\hline 4. & RG11 & SML832,ML613 and ML818, ML613 \\
\hline 5. & RG14 & SML832,ML613 \\
\hline 6. & RG15 & SML832,ML613 \\
\hline 7. & MBM00101 & PAU911,SML668 \\
\hline
\end{tabular}


Fig.1-4 PCR amplification in 5 different varieties of mungbean by using 44SSR primers

\section{Figure 1}
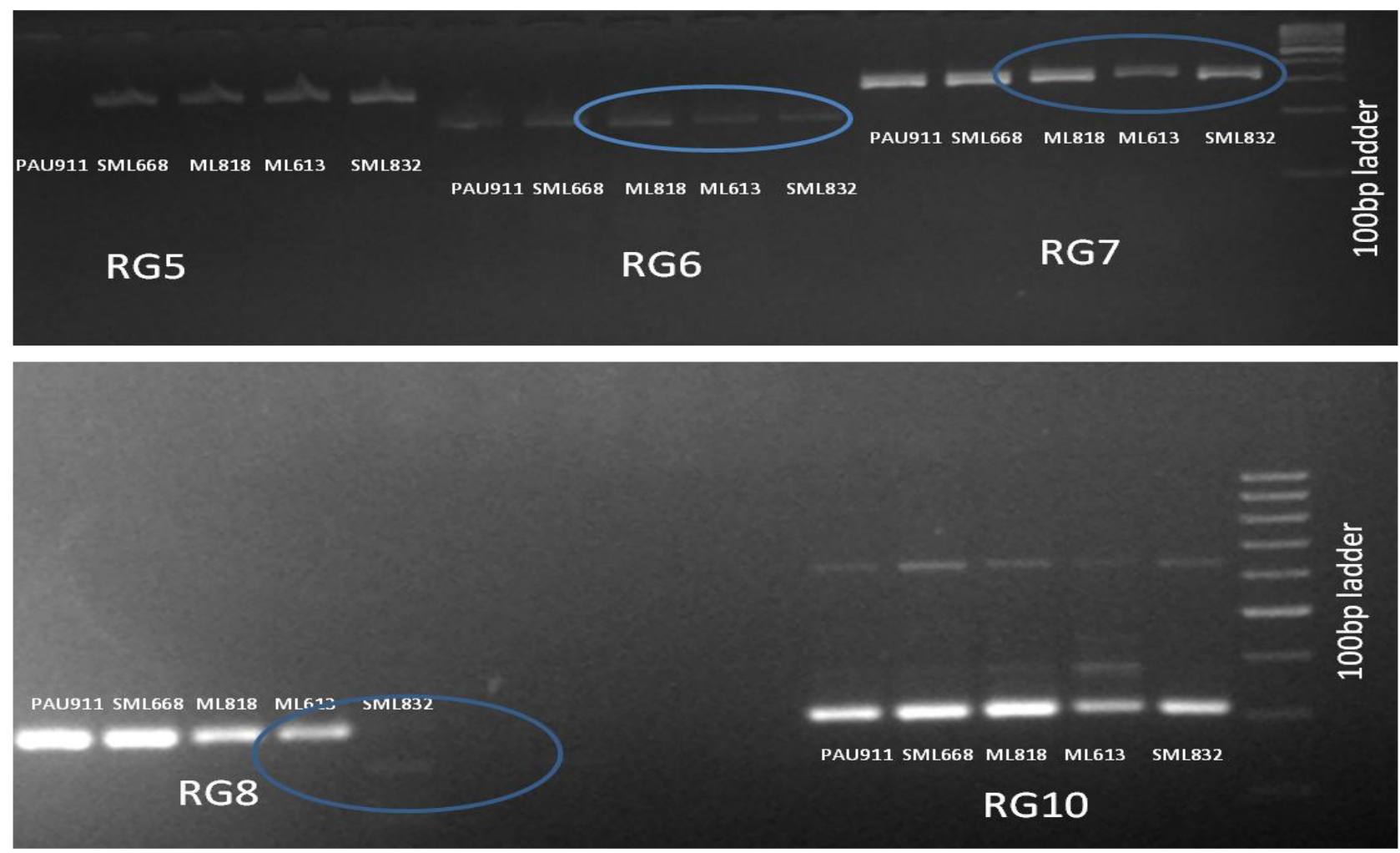

Figure 2

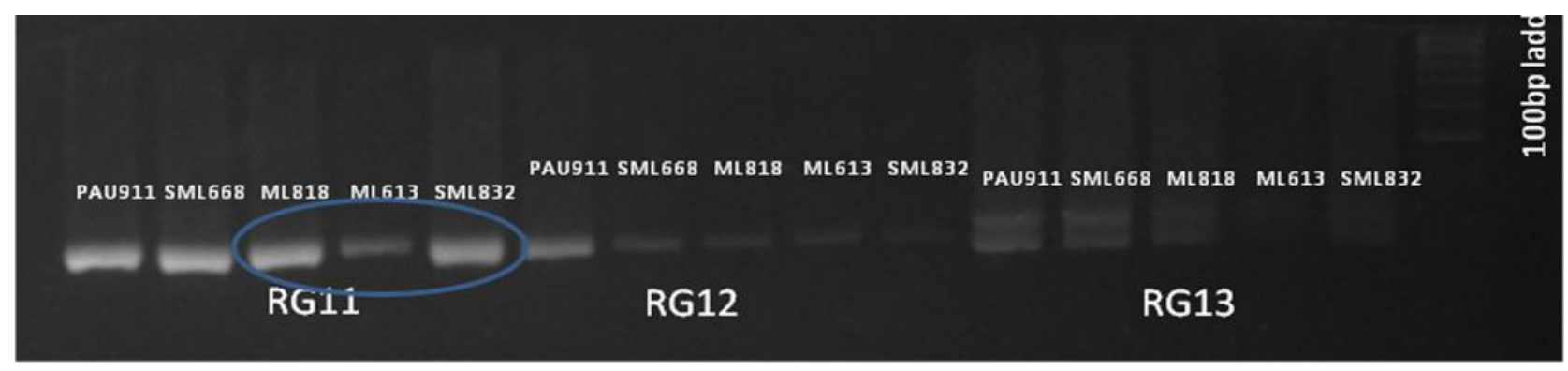

PAU911 SML668 ML818 ML613 SML832

PAU911 SML668 ML818 ML613 SML832

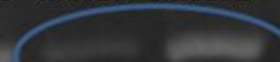

RG14

RG15 
Figure 3

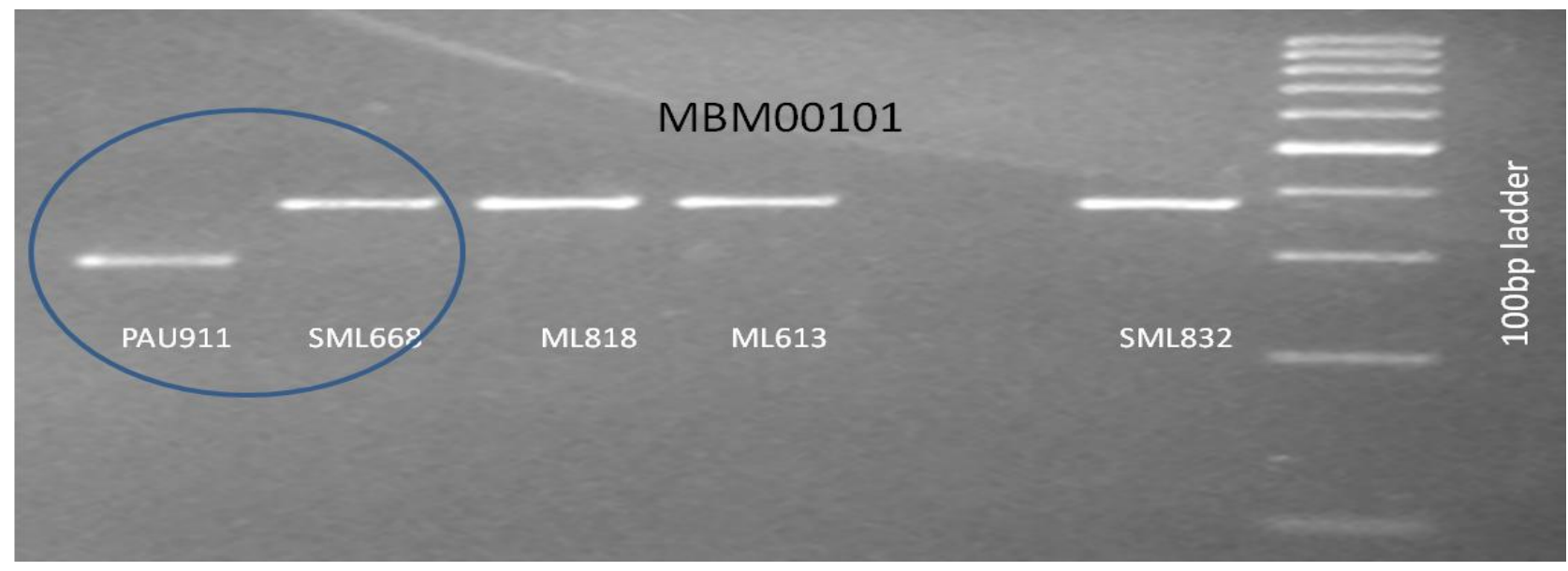

Figure 4
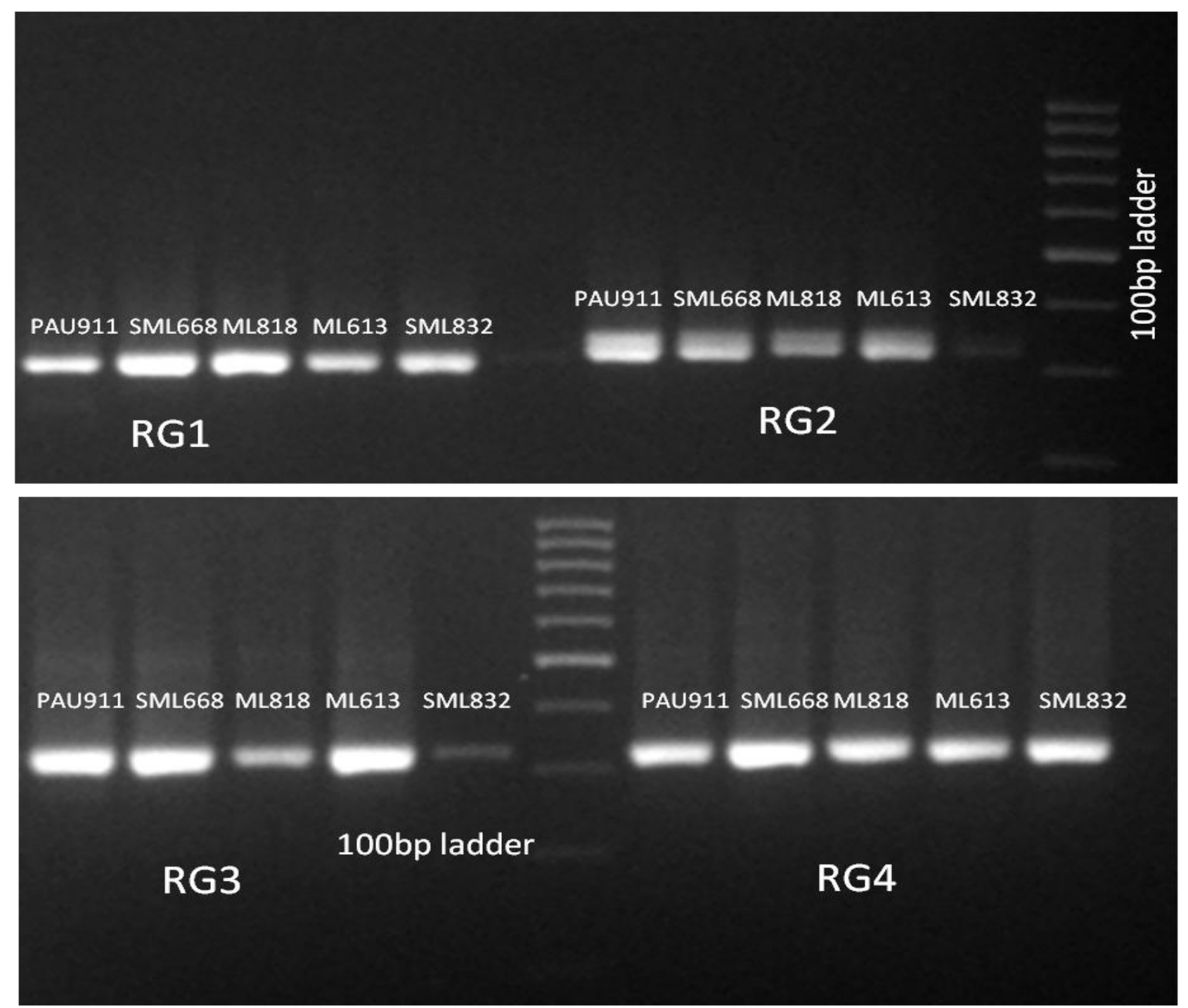
Fig.5 Dendrogram of mungbean varieties constructed using UPGMA based on 44 SSR markers

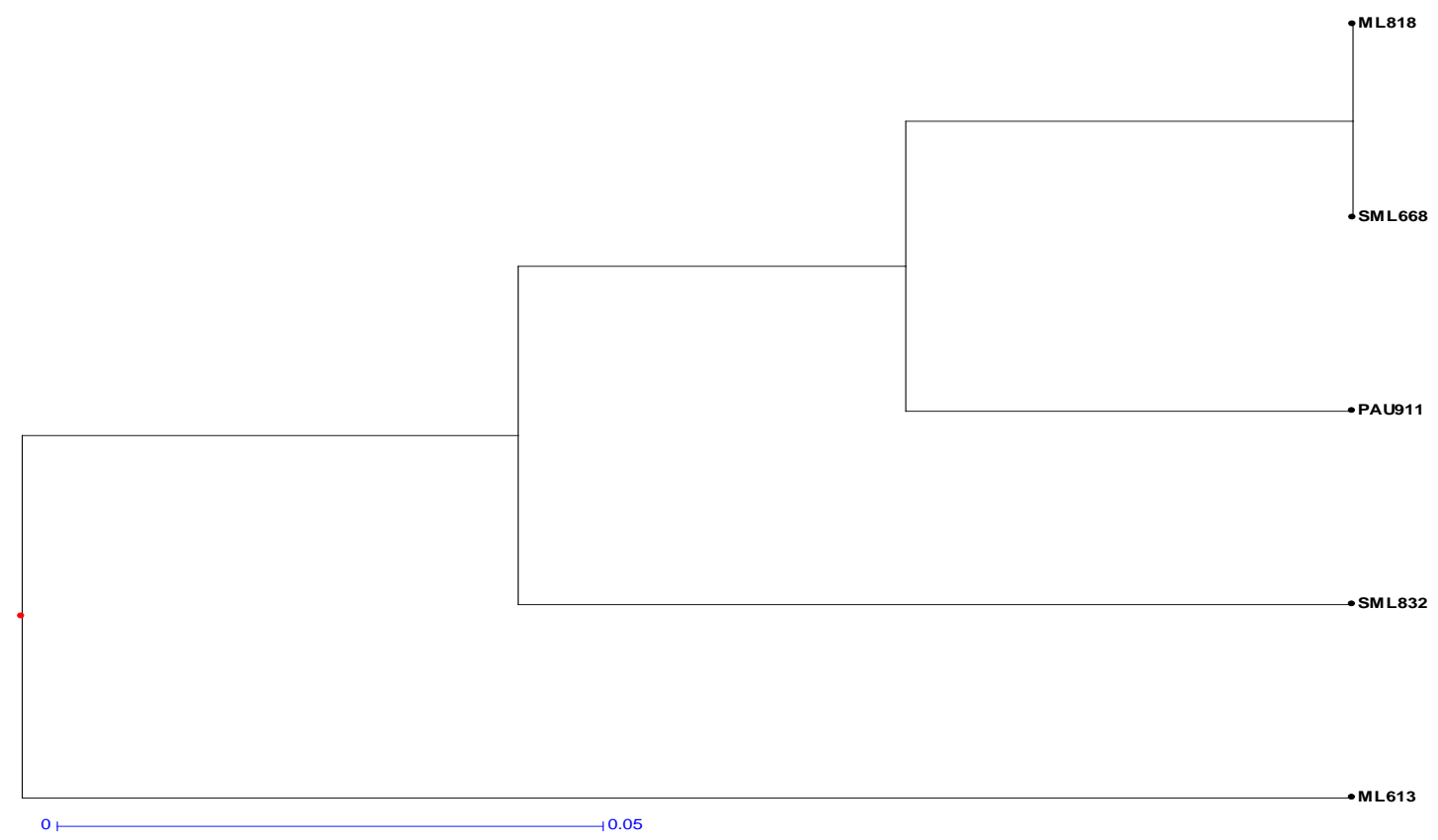

Such observations emphasis the need of molecular markers. Therefore for relevant distinctiveness among the varieties, SSR marker analysis became more significant.

\section{Molecular characterization}

For varietal characterization, molecular marker analysis was done in five mungbean varieties. For this 44 SSRs were applied, out of which 27 primers gave clear and consistent amplification profiles with all the five mungbean varieties shown in table 2 . Among these primers, 7 showed polymorphism, while 20 were monomorphic presented in table 3 . Remaining primers failed to show amplification, revealing no bands (null allele) or failed to amplify for more than one variety. The similarity co- efficient values were used to construct the UPGMA (Unweighted Pair Group Method on Arithmetic Average) presented in figure 5. The dendrogram depicting the genetic relationships generated using DARwin 5.0 Programme classified the varieties into three distinct groups, withcv.ML818 andSML668 showing highest genetic similarity, whereas, ML613 was highly distinct from other varieties. Likewise, PAU911 and SML832 also showed the genetic variation. Grouping of the genotypes as revealed by the clustering analysis was congruent with the pedigree and breeding history of the varieties. DNA marker analysis makes it possible for researchers to pinpoint specific fingerprint and accurately identify a particular genotype. It has been found that DNA fingerprinting profile for the genotype ML818 and SML832 by the primers the RG6 and RG7, for SML832 and ML613 by RG8, RG11, RG14 and RG15 positions is unique and presented in figures 1-3. Likewise in figure 3, genotypes PAU911 and SML668 with MBM00101 primer showed the unique bands. Similarly RG11 also resulted into differentiation between ML818 and ML613 shown in figure 2. SML668, PAU911 and SML832 showed similarity as most of the markers showed the monomorphic DNA 
barcoding presented in figure 4 . Thus from the above investigation, it may be concluded that molecular analysis revealed substantial polymorphism in these mungbean varieties. The technique may be used to obtain reasonably precise information on genetic relationship among mungbean genotypes. Such information may be useful for selecting the diverse parents and monitoring the genetic diversity periodically in the breeder's working collection of mungbean. It is very useful for variety testing and genetic purity. Extensive molecular diversity analysis was done by using different molecular markers using RAPD markers, Sunitha et al., (2012) using 24 ISSR markers and Wang et al., (2012) using 15 SSR markers reported polymorphism in different mungbean genotypes used in their study. Genetic diversity analysis using PCR based markers (RAPD, SSR and ISSR) revealed that, higher marker indices were obtained for ISSR markers, which proved to be the most efficient marker system in terms of average heterozygosity values (Akanksha et al., 2014). The genetic diversity within released cultivars of Indian mungbean has been rather sporadic and commonly used parents in breeding programs have missed out from these studies. It has been described that diversity of Indian mungbean cultivars is narrow (Gupta et al., 2013) also reviewed genetic linkage maps, comparative genome mapping, and gene/quantitative trait loci (QTLs) mapping for agronomically important traits of this crop. Lakhanpaul et al., (2000) studied the diversity among 32 mungbean cultivars from India using RAPD markers. Singh (2003) used ISSR marker to access genetic diversity to mungbean genotypes. Bhat et al., (2005) also used AFLP marker system to assess the genetic diversity and relationship among the cultivars. The number of genome wide polymorphic SSR markers is limited for greengram (Somta et al., 2008 and Tangphatsornruang et al., 2009). Hence, the diversity profiles of these genotypes could be exploited for future varietal identification. It was thus concluded that morphologically flower and vein colour distinguish the PAU911 variety from rest of the varieties under study. But SSR markers currently used could precisely distinguish all the five varieties from each other. Therefore these SSR markers can further be exploited to differentiate other mungbean genotypes.

\section{References}

Akanksha, S., Dikshit, H.K., Neelu, J., Singh, D.and Yadav, R.N. (2014).Efficiency of SSR, ISSR and RAPD markers in molecular characterization of mungbean and other Vigna species. Indian J. Biotechnol., 13: 81-8.

Bhat, K.V., Lakhanpaul, S.and Chadha, S. (2005). Amplified fragment length polymorphism (AFLP) analysis of genetic diversity in Indian moongbean (Vigna radiate (L.) Wikzek cultivars. Indian J. Biotechnol., 4: 56-64.

Bornet, B., Muller, C., Paulus, F.and Branchard, M. (2002). High informative nature of Inter Simple Sequence Repeat (ISSR) sequences amplified with triand tetra-nucleotide primers from cauliflower (Brassica oleracea var. botrytis L.) DNA. Genome, 45: 890-6.

Dikshit, H.K., Sharma, T.R., Singh, B.B. and Kumari, J. (2009). Molecular and morphological characterization of fixed lines from diverse cross in Munbean (Vigna radiata (L.) Wikzek). Genetics, 88: 3.

Gupta, S.K. and Gopalakrishna, T. (2013).Advances in genome mapping in orphan grain legumes of genus Vigna. Indian J. Genetics Plant Breed., 73: 113.

Lakhanpaul, S., Chadaha, S.and Bhat, K.V. (2000). Random amplified polymorphic DNA (RAPD) analysis in Indian mungbean [Vigna radiata (L.) Wikzek] cultivars. Genetica, 109: 227-34. 
Litt, M., and Luty, J.A. (1989). A hypervariable microsatellite revealed by in vitro amplification of a dinucleotide repeat within the cardiac muscle actin gene. Am. J. Hum. Genetics, 44: 39701.

Manivannam, A., Anandakumar, C.R., Ushakumari, R. and Dahiya, G.s (2016).Characterization of Indian clusterbean (Cyamopsis tetragonoloba (L.)Taub.)genotypes using qualitative morphological traits. Genet. Resour. Crop Evol., 63: 483-93.

Naresh, V., Yamini, K.N., Rajendra, Kumar, P. and Dineshkumar, V. (2009).ESTSSR markerbased for the genetic purity assessment of safflower hybrids. Euphytica, 170: 347-53.

Saghai-Maroof, M.A., Soliman, K.M., Jorgensen, R.A., Allard, R.W. (1984). Ribosomal DNAsepacer-length polymorphism in barley: Mendelian inheritance, chromosomal location, and population dynamics. Proc. Natl. Aca. Sci., 81:8014-9

Singh, S. (2003).DNA markers in mungbean. $\mathrm{Ph} . \mathrm{D}$. thesis, University of Mumbai, India.

Somta, P., Musch, W., Kongsamai, B., Chanprame, S., Nakasathien, S., Toojinda, T., Sorajjapinun, W., Seehalak, W., Tragoonrung, S. and Srinives, P. (2008). New microsatellite markers isolated from mungbean [Vigna radiata (L.) Wilczek]. Mol. Ecol. Resources, 8:1155-7.

Sunitha, S., Srinivasulu, R.K.and Narendra, J. (2012). Genetic diversity analyses of mungbean (Vigna radiata $($ L.) Wilczek) by ISSR. Int. J. Plant Breed., 6(2): 7383.

Tangphatsornruang, S., Somta, P., Uthaipaisanwong, P.and Chanprasert, J. (2009). Characterization of microsatellites and gene contents from genome shotgun sequences of mungbean [Vigna radiata $(\mathrm{L}$.$) Wilczek].$ BioMed Central Plant Biol., 9: 137-48.

Tautz, D.and Renz, P. (1984). Simple sequences are ubiquitous repetitive components of eukaryotic genome. Nucleic Acids Res., 12: 4127-38.

Van, K., Kang, Y.J., Han, K.S., Lee, Y.H., Gwag, J.G., Moon, J.K.and Lee, S.H. (2013).Genome-wide SNP discovery in mungbean by IlluminaHiSeq. Theor. Appl. Genetics, 126: 2017-27.

Varshney, R.K., Graner, A.and Sorells, M.E. (2005). Genic microsatellite markers in plants: features and applications. Trends Biotechnol., 23: 48-55.

Wang, X.Q., Kwon, S.W.and Park, Y.J. (2012).Comparison of Population Genetic Structures between Asian and American Mungbean Accessions Using SSR Markers. J. Agricult. Sci., 4(9): $150-8$.

\section{How to cite this article:}

Rupinder Kaur, A.K. Toor, Geeta Bassi and Bains, T.S. 2017. Characterization of Mungbean (Vigna radiata L. Wilczek) Varieties using Morphological and Molecular Descriptors. Int.J.Curr.Microbiol.App.Sci. 6(6): 1609-1618. doi: https://doi.org/10.20546/ijcmas.2017.606.189 